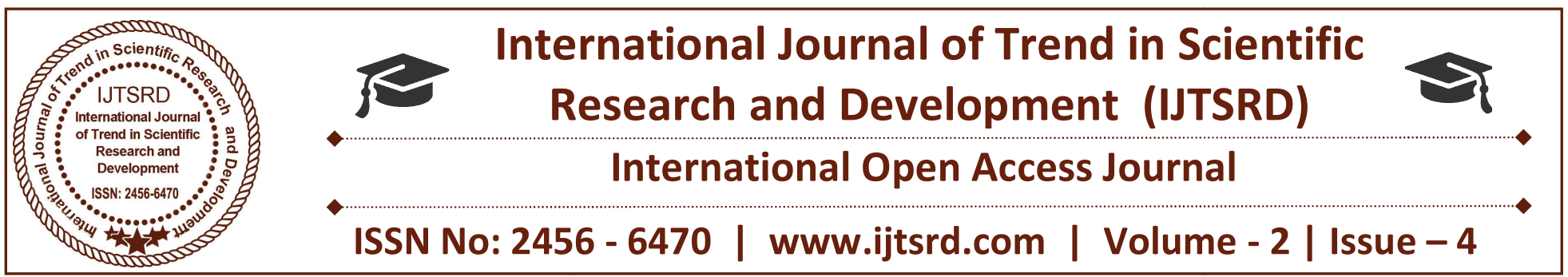

\title{
The Threads of Emotions- Phulkari
}

\author{
DR. Prof Amarjeet Kaur, Ankita Kallan \\ RIMT University, Mandi Gobindarh, Punjab, India
}

\section{ABSTRACT}

Indian embroideries represents the culture as well as creative and artistic skills possessed and inherited by the craftsmen of different states. These embroideries displays their bond with their soil and to the surroundings where they were evolved or were popularly practised since centuries. Phulkari is a traditional style of embroidery of Punjab, famous for its unique embroidery stitches. Due to globalization and colonization, this embroidery has diminished but the love for this craft has helped to retrieve this embroidery form with new and advance modern techniques. Traditional motifs are contemporized with the help of digital softwares like CAD/CAM, Photopaint softwares etc. The traditional time consuming and hardworking methods are replaced with the latest automatic machines which helps in more production at a high speed. This research paper would help to mix traditional phulkari embroidery with modernity, so that the embroidery could survive within modern fashion market. It would not only help to create new articles for the modern customers but also will help to keep our craft alive.By Ankita kallanGuide - Dr ( prof) Amarjeet kaurResearch SCholarRimt university Mandigobindarh.

Keywords: Phulkari, Embroidery, Digital Softwares

\section{INTRODUCTION}

Phulkari has been an art form of elegance and prestige since centuries. It has lent to an aesthetic and artistic form of ornamentation in the rural society of Punjab and is a rich part of its tradition and heritage. Initially, it was a simplistic form of custom and home craft not meant for sale but a leisure activity within homes with cultural significance.
Gradually, it was adopted into the economy during the colonial era when it was exhibited in international exhibitions. As time passed, it began to be used as a source of income in small setups as well as in national exhibitions. The rise of ethnic crafts came about leading to its commercialization.

It has been an epitome of tradition and grace. It has been witness to every festivity and celebration in Punjab. The fascinating flower work has been a part of ancient history as is known through the story of Heer Ranjha. It reveals the inner sensitivity towards life and art through the skillful presentation of phulkari. Combining utility and finesse it has passed through the centuries as an important part of trousseau for women.

Michael (2009) explained that the bride's family presented the groom's relations with bagh and phulkaris, which composed a part of her dowry. The researcher also reported that when a new mother left her room for the first time on the eleventh day after the birth of a child, she wore a phulkari. Simultaneously, a large embroidered cloth -the lesser ricjly worked til patra used to be distributed to the other men and women in the house.

In traditional phulkari pieces each motif was woven thread by thread into an exquisite pattern. Hundreds of patterns inspired from daily life, domestic space and nature became the inspiration for their designs have moved to museums and collectors while NGO's are working for the survival of this rural art.

Embroidery forms experienced a dip with the partition of India and Pakistan. However, in no time it sprung back like an evergreen style. Although there is an inimitable demand for Phulkari work even today, 
there are limited authentic and credible sources left from where one can purchase a hand-woven Phulkari fabric. With commercialization of the needlework, quicker methods of production were devised.

Initally the dyeing pigment which was used was not colour-fast, a problem for which the modern times have a solution. Modern Phulkari is a much more serious business. From being a leisure activity it has transformed into becoming one of the major sources of employment for women in Punjab.

\section{Embroidery History}

Khurshid explains that the word Phulkari is a composite kind of term including two Sanskrit words phul (flower) and karya (to do) and thus means 'to do flower work'. When applied in the context of folk design, it stands for the ancient craft of embroidering flower designs with pure silk floss on a chaddar of plain rough hand woven cotton pure cloth.khaddar is made on power looms and available locally in all major city markets.

A review of literature on phulkari shows that simple embroidered chaddars of daily usage were also called Phulkari or Til Patra phulkari. Khurshid has distributed Phulkari in four major types- Phulkari, Bagh phulkari, Chobe phulkari and Shishdar phulkari. He also mentions the making of a nazar battu at the corner of the phulkari so as to avoid the evil eye.

Goyal (1998) made the border and multipurpose designs by combining the traditional motifs used in phulkari embroidery. The Cham silk and the khaddar were the fabrics selected for using the designs on them. Varied techniques like hand embroidery, machine embroidery, hand painting and screen painting were applied to the phulkari designs, quality of embroidery, colours and the kind of threads used.

Edwards (1996) in the article "Embroidery: the vanishing heritage of the Nomadic Rabari explored that in the Rabari community, embroidered clothing played an integral role in the twin system of dowry and bridal price. Veil clothing, blouses, quilts and bags in particular were important inclusions in the series of gift exchanges played as a part of th whole system of betrothal and marriage. Stitching embellishment on clothing and household items became an identity marker of the group one belonged to, marital status, function and also a testament to the skill of the maker.

Gangotra (1998) mentioned in her study how embroidery was being done on articles of apparel used by men and women. Various number of stitches were used to embroider the articles. Common motifs embroidered were floral and birds. Many changes in embroidery were reported over time with respect to desigs, quality of embroidery, colours and also the kinds of thread used.

I want to study the impact this form of embroidery has had on women and its presence in its struggle for survival as an art form. The preservation of phulkari and bagh embroideries is one of the concerns today. Organizations such as Dastaar and SEWA have done a lot for the promotion of these two embroidery forms. Efforts for its revival can be seen with workshops and events like '1469' and 'Mela Phulkari' organized at The India Habitat Centre. Through a strategy of experimentation and fusion, phulkari can be preserved.

Its association with the cultural and social milieu will be focused on. From being a domestic craft to a commercial success it definitely has come a long way. It held strong emotions as it was presented on important occasions like weddings and social festivities. Now it has given employment to thousands of women as a means towards financial independence.

Many banks like NABRAD and institutions promoting handicrafts like CAPAD gave subsidies for the formation of self help groups through which women could sit at home and embroider for various NGO's. Many others like NABARD, SIDBI, KVIC, DC(Handicrafts) etc are working in the country for the revival of traditional forms of embroidery.

Phulkari is not merely a beautifully embroidered cloth, but was an essential component of the life of an average Punjabi woman. The primary focus is to examine the journey of design on this fabric. It presents empirical documentation of patterns used in the past and the changes that these designs have undergone in the last two decades in particular after the tradition of Phulkari was revived and commoditized.

It relies on primary data which has been collected from various villages and cities of Punjab. The data was made with the help of qualitative methods using tools of quasi-participant observation, case history method along with focused group discussions and narratives. Interviews of the old women, artisans, shopkeepers and middlemen were conducted over a period of three years.

The various changes which have occurred through the years in color, motif and material will be studied. In 
the last three decades this form of embroidery has gathered immense popularity. While many kinds exist, more repetition is seen now due to mass production rather than the unique ideas of every woman as was in the past. As rural women are well trained in the art of sewing and embroidery, it has worked amazingly as a commercial as well as a social project.

\section{Origin and History}

Many Punjabi folk songs and the romantic epic saga of 'Heer Ranjha' also have instances about Phulkari crafts. During the reign of Maharaja Ranjit Singh, Phulkari flourished in Punjab as women would engage themselves in weaving this craft at their leisure, as they bonded with friends, relatives and neighbours.

Elderly women of Punjabi households encouraged the skill of stitching Phulkari in their children, who passed it on to their future generations. Silk threads or 'pat' were utilized in composing the deft motifs and patterns on dupattas, shawls or Baghs. The founder of Sikhism, Guru Nanak Dev (A.D. 1469-1538) in his recitations gives prominence to embroidery regards it as an integral part of feminine duty. He recites in his scriptures - "Kadh kasida pahreh choli tan tu jane nari" implying that a woman establishes her feminine identity only when she knows how to embroider her own costumes.

Historically, embroidery was perpetuated and formed as a part of social rituals. Wearing of symbolic phulkari embroidered odhini (head scarf) by the women of the household was part of the rites de passage of the Punjabi household.

\section{Diversity in Motifs}

Religious boundaries blurred when women from different religions got together to embroider. Women respondents in the course of interviews told us that everyone in the village irrespective of the religion, whether Hindu, Sikh or Muslim embroidered phulkari. They helped each other in weaving and embroidering.

There is not much evidence to suggest that phulkari had any ceremonial value during wedding ceremonies within Muslims but there were many stories which supplement that wearing and embroidering of phulkaris was as popular among Muslim women as it was among the Hindu and Sikh women in both rural and metropolitan parts of Punjab.
Hand spun, hand woven khaddar was used in phulkari making as suggested earlier because of its ready availability and cost effectiveness. Learning to spin cotton was part of primary socialization of a girl child. Unmarried girls used to sit in groups (called as trinjan) and spun cotton throughout the night. This khaddar was made on looms that use to be present in the average village household.

However, many women preferred to give it to a professional weaver locally called julaha. Usually two or two and a half widths were joined together along its entire length to form a complete base for phulkari. Some women joined two strips of the woven fabric and others opted to join two and a half strips, depending on the desired length and width desired for the wrap. The fabric was usually dyed at home, but it was also given to a professional dyer called lalari.

Two types of embroidery thread were used: pat (untwisted silken floss) and white cotton yarn. Pat was considered a pure thread (suchha dhaga). It was available in the form of skeins (lachhiyan/ guttiyan) and being an expensive yarn was sold per tola (traditional South Asian unit of mass). The yarn was usually bought in bulk to embroider many phulkaris or baghs by the elder women of the house.

White yarn was available in the form of spools and was not a glossy yarn. Other than white cotton yarn, white pat thread was also used. Fabric colour was always nabhi (tones of red), as every colour looks good on this base (is par har rang khilta hai). Other base colours such as black, brown, blue and even green were used for making phulkari but to a lesser extent. Colours of embroidery thread were khatta (yellow/orange), gulabi (pink), hara/angoori (green) in pat and white cotton yarn.

The first colour to be filled on the base was especially yellow and other colours then followed. The amount of white yarn was less in comparison with the coloured pat and filled in the end as it used to get dirty easily. There were phulkaris/ baghs with one single colour also, especially the golden/yellow colour. Harmony in the blending of colour and vibrancy of patterns made the phulkari unique .

Imagination and creativity combined together created hundreds of patterns and it is these designs that continue to witness dramatic evolution even today. One of the stated object give of this paper is to document these designs and changes that the phulkari has witnessed after its resurrection and commoditization. The next section presents varieties 
of these designs collected from both primary and secondary sources.

\section{Concentration of Phulkari Crafts in India}

Part in Northern Punjab, specially the Chakwal and Hazara manufacture some of the best Phulkari crafted garments and Baghs. The states of Haryana, Punjab and Gujarat boast of rich Phulkari crafts, prevalent since ages. The silk threads used to stitch Phulkari are obtained from Kashmir, Bengal (now West Bengal) and the country of Afghanistan. The region of Patiala in Punjab is a sought after location renowned for its beautiful Phulkaris.

\section{Features of Phulkari Crafts of India}

The chief characteristics of Phulkari embroidery are the use of darn stitch on the wrong side of coarse cotton cloth with coloured silken thread. The silk threads of golden yellow, crimson, red, orange, green and pink are usually used for the embroidery. Worthy to note is that a single strand was used at a time, each part worked in one colour and the different colour effect is obtained by clever use of horizontal, vertical or diagonal stitches.

The Phulkaris in Punjab are of two types, one carrying a regular row of stylized motifs either of flowers, fruits or birds and other carrying a rich repertoire of the folklore and motifs taken from everyday life. The centre often carries a stylized lotus form the two cross borders at the two cross borders at the ends carry rows of stylized lotus form, the two cross borders at the ends carry rows of stylized animals and bird forms, or flowers. The remaining surface is covered with a plethora of motifs like a train on wheels carrying human forms, birds and animals rushing across the horizon as peacocks move across the surface and strange mythical birds and animals mingle together in harmony.

In the past, this craft was a purely domestic craft, which was never sold in markets. Various shades of red and the colour itself being highly favoured as an appropriate colour for Phulkari clothes is considered one of the most auspicious colours in Hinduism and Sikhism. Brown, white, black and blue are the other popular colours which employ Phulkari art.

Aged Punjabi ladies are quite fond of wearing white coloured Phulkari crafts. Embroidery in Punjab was a community activity. Women would sit in groups and embroider during their leisure hours talking to each other. Each piece of embroidery became a canvas personifying individual imagination and skill.
Togetherness inculcates feeling of caring, sharing, exchange of ideas, neighbourliness, bonding and the fact that both Hindu and Muslim women residing in proximity embroidered together, communal harmony in the region was exemplary. Devayani Mitra explained that though there was a wide spread of regional areas where Phulkaris and Baghs were stitched by women, but there existed a regional variation especially those produced in West Punjab were considered to be fine and of best quality as compared to the East Punjab.

There were hundreds of highly imaginative Phulkari patterns: geometrical shapes including lozenges, squares, triangles forming various designs as kites, peacock, rolling pin, train, vegetables, fruits, kitchen equipments, as well as figured designs and familiar objects in the rural environment as animals, plants, sun, moon, , farm, fields jasmine, marigold flowers, comb, mirror, cotton balls dagger, jewellery like hansali, waves of the sea, tika, karda, folk depictions as village scenes and humans either prepared by counting the yarns or tracing the complicated designs in outline with black ink and then filling them in with darning stitch. These designs and motifs are an expression of the embroiderer's thoughts and aspirations or observations of life around her.

There used to be a distinct preference for geometrical designs as it was easier to embroider by counting thread on the fabric. It could be the motifs of the objects or its stylized form. Many objects that were embroidered ranged from food items, vegetables, birds, animals, household articles, jewellery, etc.

Anaranwali phulkari involves every flower looking like a pomegranate. Gulkherain di phulkari was a famous phulkari of flowers as Gulkhera means phul khile hon (blooming flowers). The design and shape of gulkherae can vary. There were various phulkaris that we came across during the fieldwork, to be referred as gulkherayan di phulkari but designs or motifs in all these were different though women embroidering these would refer to these by local textual names. Thw Kapah tindyan di (cotton balls) phulkari, ladoo (sweet ball) phulkari etc. are some of the names mentioned by women embroiderers.

\section{Types of Phulkari Embroidery}

\section{-Panchranga Bagh}

It means five colours. It is decorated with chevrons of five different colours. Similarly pieces like satranga which is seven colours are also available. 
-Chope

It is red coloured cloth with embroidered border presented to the bride by her grandmother during a ceremony before the wedding.

-Vari da Bagh

It is made on red cloth with yellow golden embroidery symbolizing happiness and fertility. The whole cloth has patterns smaller ones within the borders and intricately worked in various colours.

-Ghungat bagh

It means covering of the head. It has a small border on all four sides. In the centre of every side, a big triangular motif is worked.

-Bawan Bagh

It means fifty two in Punjabi and has as amny geometrical patterns.

-Darshan dwar

The gate offers a view of the deity and is presented in temples to adorn the walls of the home when the Granth Sahib is brought to the house. The theme is of a decorative gate.

-Surajmukhi

The sunflower remains the central pattern in this phulkari.it is a unique blend of the Holbein stitch and regular darning stitch.

-Suber

It is worn by the bride during marriage rites. It includes five motifs. One is central and four at the corners.

-Chamba

It is a hybrid phulkari having varied stylized creepers, flowers and leaves.

-Sanchi phulkari

It is a narrative form of embroidery showing slices of life in south east Punjab.

\section{-Meenakari}

This type or the Ikka bagh is often made of white and gold coloured pat, is decorated with colorful lozenges referring to enamel work.

-Kaudi phulkari

These include chains of small white squares representing stylized cowries. They symbolize fertility and good luck.

\section{Innovations in Phulkari}

Increasing demand of this embroidery from various parts of the world has been the nucleus of change that the tradition of Phulkari has witnessed. Having bagged a contemporary label, the Phulkari today is a lot different. For example, no longer is the darn embroidered on the other wrong side of the cloth. A coarser style of embroidery that showcases mechanical work instead of detailed handwork, is being used a lot by the industry owing to the heavy demand of the embroidered fabrics. Likewise, Khaddar is being replaced by a variety of other textiles such as chiffon, georgette, cotton, etc.

New designs for outfits are being established by several modern designers to reach out to the new segments of customers. Presently, machine made Phulkari attires are being manufactured in Amritsar and Ludhiana which is affordable for low end customers. Almost twelve phulkari suits can be made in one day by machines which lower the price of the product. Nevertheless, the machine made products have not reduced the sale of traditional Phulkari, instead new markets have opened up popularizing it, making it available to masses.

\section{Wearing Phulkari}

A Phulkari suit or sari styled with ethnic jewelry in contrast colours looks amazing. Accessorizing Phulakari outfits with oxidized silver jewellery can be a complete traditional look.

Traditionally considered a bridal outfit, the Phulkari is till date wily worn during the wedding season in a family. Bright reds, oranges and blues add a vibrant and joyous touch to their celebrations. Nonetheless, lighter Phulkari works dyed in sober colours make elegant daily wears. Since Phulkari is a form of embroidery that can be done on almost any fabric, seasonal variations are not a limitation for its suitability. Phulkari odinis and dupattas can be worn with plain kurti-patiala or a cotton top worn over rugged denim for a contemporary look.

\section{Global Appeal}

Phulkari work is a trending global wear option. With people from all around the world exhibiting enthusiasm to indulge in Indian culture, Phulkari has easily slipped into the Western countries. Owing to its ease all over the year, the fashion rates quite high on the global wearability factor. Depending on the occasion the Phulkari can be customized for occasional or regular dressing. 


\section{Application of CAD for textiles designing/embroidery}

Rise in technology has lent to the flourishing and commercialization of Phulkari. Computer Aided textile Designing is the hope in today's era. Advanced computer systems of 2 and 3 dimensional concept designs are widely used in developed countries.

Secor and Carpenter(1996) showed that the primary reason the countries used CAD was speed, flexibility, versitality and creativity. A positive significant was found to be in enhancing creativity and styling.

Aggarwal and Gehlot (1999) found that CAD lead to better flexibility and versitality in developing design, efficiency and actual marketing.

\section{The Future of Phulkari}

Phulkari work has spread its fabric from Odinis to full-length suits. The time is not far when we will see it being used on curtains as an essential part of the interiors industry. The rural crafts industry could see Phulkari developing as a trend in designing handicrafts and ornaments as well. The very fact that it has survived and flourished beautifully over the centuries shows that it has a long way to go.

\section{Maintenance}

Phulkari is one of the most detailed and intricate methods of needlework which need proper care. A phulkari garment should be washed with delicately and ironed on the reverse side. Occasionally, a frequent dry-clean will keep the fabric bright and lively. Proper care and maintenance of any fabric , silk thread work in this case leads to its good appearance in the long run.

\section{Interesting Facts and Comparisons}

1. The silk thread which was used traditionally in Phulkari work was straighter than an uncoiled steel wire.

2. Indian fashion designer Maneesh Malhotra based his entir show on the embroidered fabric.

3. Anushka Sharma adorned phulkari suits in the movie Phillauri.

4. Aishwarya Rai wore phulari dupattas in the movie Sarabjit.

5. A heavy phulkari work dupatta can cost almost as much as a Benarasi silk saree.

6. Phulkari embroidery uses the least complex patterns to create extremely intriguing designs

7. Originally Phulkari was done as a pass time by women of Punjab
8. It takes at least 80 days to finish a Phulkari salwar kameez

9. The first mentions of Phulkari work were found in the Punjabi text on Heer and Ranjha

10. The patterns of Phulkari are not drawn or traced

11. Bollywood actress Priyanka Chopra wore a Phulkari Churidar Kameez in her movie 'Teri Meri Kahani'

\section{Process of Making Phulkari Crafts of India}

The word Phulkari means flowering and it also creates a flowery surface. The stitch derives its grace from the use of darning stitch placed in different directions which are the vertical, horizontal and diagonal. The embroidery is done from the reverse side. The pattern is controlled by counting of thread, but quite often the outline of pattern is embroidered on the cloth in green thread.

The needle picks up just one thread at a time, so that the backside of pattern is delineated with single lines of colour in extremely fine stitches. In the front the stitch ranges from $\mathrm{A} 1 / 2$ to $\mathrm{A} 1 / 4 \mathrm{cms}$ in size. The stitching is done by using silk thread, though occasionally cotton threads in white and green are used, and sometimes even woollen.

A specificity of Phulkari is that the fabric itself is used in a geometric way as an inner decoration, so that the medallions and diamonds, etc are not just patterns sewn on but become an integrated combination of unique colours, yellow and madder brown. This is only possible where absolute accuracy in thread counting is observed. In Bagh, the stitch is very refined such that the embroidery itself becomes the fabric. The quality of the workmanship is measured by the smoothness at the back that can only result from the evenness of the stitches.

The smaller the stitch, finer is the quality of the embroidery. Apart from scarves and dupattas or shawls, Phulkari work is also done on shirts, 'salwar kameez' and bed covers. The Indian government is making attempts to promote this unique craft by organizing many exhibitions, fairs and training programs across the nation.

Today, several fashion designers are introducing Phulkari crafts into a variety of accessories like bags, shoes, 'jootis', table mats, jackets, cushion covers, slippers and children's garments. The organisations of Punjab Small Industries and Export Corporation (PSIEC) gives opportunities to the local women of 
Punjab to sell their Phulkari crafted products for higher profits, in order to encourage Phulkari artisans to keep their tradition alive.

\section{The Effect of Colonization on Phulkari}

Phulkaris and Baghs which a bride acquired as a part of her trousseau - the number and the heaviness of embroidery, was a reflection of bride's talent and the teaching she received from her mother. There was a trend of giving at least twenty-one Phulkaris in trousseau during the nineteenth century.The financial status was assumed through the intricacy and amount of silk floss used in embroidering Phulkari.

The maternal mother, grandmother used to take special pains, care, interest, attention and pride in embroidering the same. Punjabi girl from an early age had also to work on it, which showed her skill, creativity and hard work representing her eligibility as bride.

With the coming of the colonial appreciation of Phulkari embroidery, also came the decline of Phulkari embroidery for personal and ceremonial purpose. Phulkari was transported by the British to many exhibitions not for exhibiting the rich tradition of embroidery popular in both East and West Punjab in pre-partition India, but also with the intent to explore its commercial viability in the International market.

It was not that there were no admirers of this embroidery as is evidenced in George Watt's catalogue to the exhibition of Indian Art held in Delhi in 1903 in which, he categorically insists on the need to study Hazara Phulkaris in particular. But it was the commercial aspect of it that encouraged women to embroider for payment that was earlier unknown to them.

Poverty was one of the potent factors that forced women to sell their treasures of textiles. Prior to its commercialization in the colonial era, women embroidered as a leisure activity, but now demands of the market and revenue generated from its sale reduced it to a routine affair to be pursued under pressures of deadlines and for an unknown customer.

\section{Globalization and Revival of Phulkari}

Hitkari converses that after independence industrialization, influence of western culture through films, radio and television promoted materialism and consumerism resulting in the decline of traditional art and craft. Phulkaris and Baghs were confined to the old trunks, brought out occasionally to air or to be sold in times of dire needs to vendors. Light weight and finely woven fabrics like organdie, chiffon, georgette or machine made polyester, rayon and wool with machine embroidery flooded Indian markets.

Spinning at home along with the spinning wheel was gradually confined to the realm of history with its symbolic revocation with freedom movement and Gandhi. People like Kamala Devi Chattopadhaya, Pupul Jaykar and organizations like Crafts council, Regional design and weaving centers made concerted and deliberate attempts to preserve traditional crafts and made genuine efforts to revive these with the support of the state funding.

Mrinal Kanti elaborates the joint endeavors of the 'Handloom Board' and 'Handicrafts Board' for encouraging local weavers and artisans all over India in forming cooperatives, bringing the best of indigenous designs out of them. Separate department of Handicrafts were created, Museums exhibiting rare specimens of embroidery were granted space and state support. Commercial arm for promoting ethnic crafts in the form of state emporiums was established in the commercial hub of the capital city Delhi.

Presidential awards were announced for master craft persons from different field at regular intervals. Exigencies of livelihood and reducing interest in the economic value of Phulkari also affected the traditional methods of teaching of craft from one generation to another.

Revivalist insisted on original form wanting the embroidery to be done only on Khaddar with silken floss thread (Pat) from the wrong side of the cloth by counting of threads. There were few traditional hands available to meet this expectation. Designers from India and abroad bought old Phulkari and Baghs from vendors at a pittance and cut these into pieces and reembellished them in their designer outfits without acknowledging its original form or its ethnicity.

\section{Agencies of Revival}

Commodification of marketable goods uses many instrumentalities to expand its reach. These external agencies include state, private enterprise and some influential fashion designers and local merchants. Government of India in the year 1952 established 'The All India Handicrafts Board' with the intent of finding some answers to several problems being faced by the handicraft workers in India.

This board promoted handicrafts through interventions like many popular exhibitions and fairs 
at district, state and national level which provide a strong platform for craftsmen to sell their wares from various parts of India like Surajkund crafts mela, Haryana; Kala Ghoda Art Festival, Mumbai; Pushkar Camel Fair, Rajasthan etc. Creation of new markets has also helped in the revival of craft.

In addition to these annual exhibitions, government has also started several nodal avenues meant for exclusive sale of handicrafts and to encourage artisans to sell their products directly to the customers. One such venture was Dilli Haat, established in 1994 by Delhi Tourism and Transportation Development Corporation (DTTDC) and Ministry of Textiles and Ministry of Tourism, Government of India operates in the capital city of New Delhi and mirrors ethnic India. This was followed by Dastkaar Bazaars in Delhi, Andhra Pradesh and Ranthambore. Artisans from different parts of the country come, participate, display and sell their products. The idea was to promote ethnic culture and create ethnic habitats in the heart of metropolis and urban complexes; far from their original habitats. 